\title{
A CONTRIBUTION TO THE MOSS AND LIVERWORT FLORA OF THE REBERCE NATURE RESERVE AT THE PRZEMYŚL FOOTHILLS (WESTERN CARPATHIANS, POLAND)
}

\author{
Monika Staniaszek-Kik, Robert Zubel, Ewa Fudali, Anna Rusińska, Barbara Fojcik, \\ Grzegorz Vončina, Adam Stebel, MirosŁaw Szczepański
}

B. Fojcik, Department of Botany and Nature Protection, University of Silesia, Jagiellońska 28, 40-032 Katowice, Poland, e-mail: fojcik@us.edu.pl

E. Fudali, Department of Botany and Plant Ecology, Wrocław University of Environmental and Life Sciences, pl. Grunwaldzki 24 A, 50-363 Wrocław, Poland, e-mail: ewa.fudali@gmail.com

A. Rusińska, Natural History Collections, Adam Mickiewicz University, Umultowska 89, 61-614 Poznań, Poland, e-mail: annarus@amu.edu.pl

M. Staniaszek-Kik, Department of Geobotany and Plant Ecology, University of Lodz, Banacha 12/16, 90-237 Łódź, Poland, e-mail: staniaszek@wp.pl

A. Stebel, Department of Pharmaceutical Botany, Medical University of Silesia in Katowice, Ostrogórska 30, 41-200 Sosnowiec, Poland, e-mail: astebel@sum.edu.pl

M. Szczepański, School Complex in Rybno, ul. Sportowa 24, 13-220 Rybno, Poland, e-mail: mireksz1@wp.pl

G. Vončina, Pieniny National Park, Jagiellońska 107 B, 34-450 Krościenko nad Dunajcem, Poland, e-mail: gvoncina@poczta.onet.pl

R. Zubel, Department of Botany and Mycology, Maria Curie-Skłodowska University, Akademicka 19, 20-033 Lublin, Poland, e-mail: robert.zubel@poczta.umcs.lublin.pl

(Received: January 3, 2017. Accepted: February 7, 2017)

\begin{abstract}
AвSTRACT. The paper presents the results of studies on bryophyte flora of the Reberce forest reserve located in the Przemyśl foothills. Thirty-three species of liverworts, 70 species and two varieties of mosses were found. Terrestrial (66 species) and epixylic (58) bryophytes formed the largest ecological groups in the reserve. Twenty-four protected species were also recorded, eight endangered bryophytes and six taxa considered as primeval forest species. The most interesting finds are: Bazzania trilobata, Buxbaumia viridis, Calypogeia suecica, Cephalozia catenulata, Frullania dilatata, Metzgeria conjugata, Nowellia curvifolia, Orthotrichum lyellii, O. stramineum, Trichocolea tomentella and Ulota crispa.
\end{abstract}

KeY Words: epixylic species, protected species, primeval forest species, endangered bryophytes, Dentario glandulosae-Fagetum

\section{INTRODUCTION}

Reberce is one of nine nature reserves located within the Przemyśl Foothills Landscape Park (PFLP) (Fig. 1.1). It was established in 1996 in order to protect the fragments of primeval fir forest with natural characteristics (JANICKI 2005, RĄKOWSKI et al. 2007). The reserve is located in the Bircza Municipality of the Przemyśl District in the Bircza Forest District. The forest covers 190.96 ha and is one of the largest in that Landscape Park. The study area is adjacent to the disused small airport (JANICKI 2005).
The Przemyśl Foothills, which lay in the foreland of the Bieszczady Mountains, are relatively poorly known in respect of bryology. Most of the data is very fragmentary (ReHMAnN 1879, Szafran 1968, KarCZmarz 1975, Dzwonko 1977, Szweykowski \& KoźlicKa 1977, Kozłowska 2000, Bednarek-Ochyra et al. 2011, Stebel 2011, Stebel et al. 2011, Zubel et al. 2011, Zarzecki 2012, BarabasZ-Krasny \& Soltys-LeLEK 2014). The aim of this study was to recognise the diversity of bryophyte species of the Reberce reserve. This study is one of three (Chwaniów reserve - Stebel et al., Na Opalonym reserve - Fojcik et al., 
Monika Staniaszek-Kik et al.
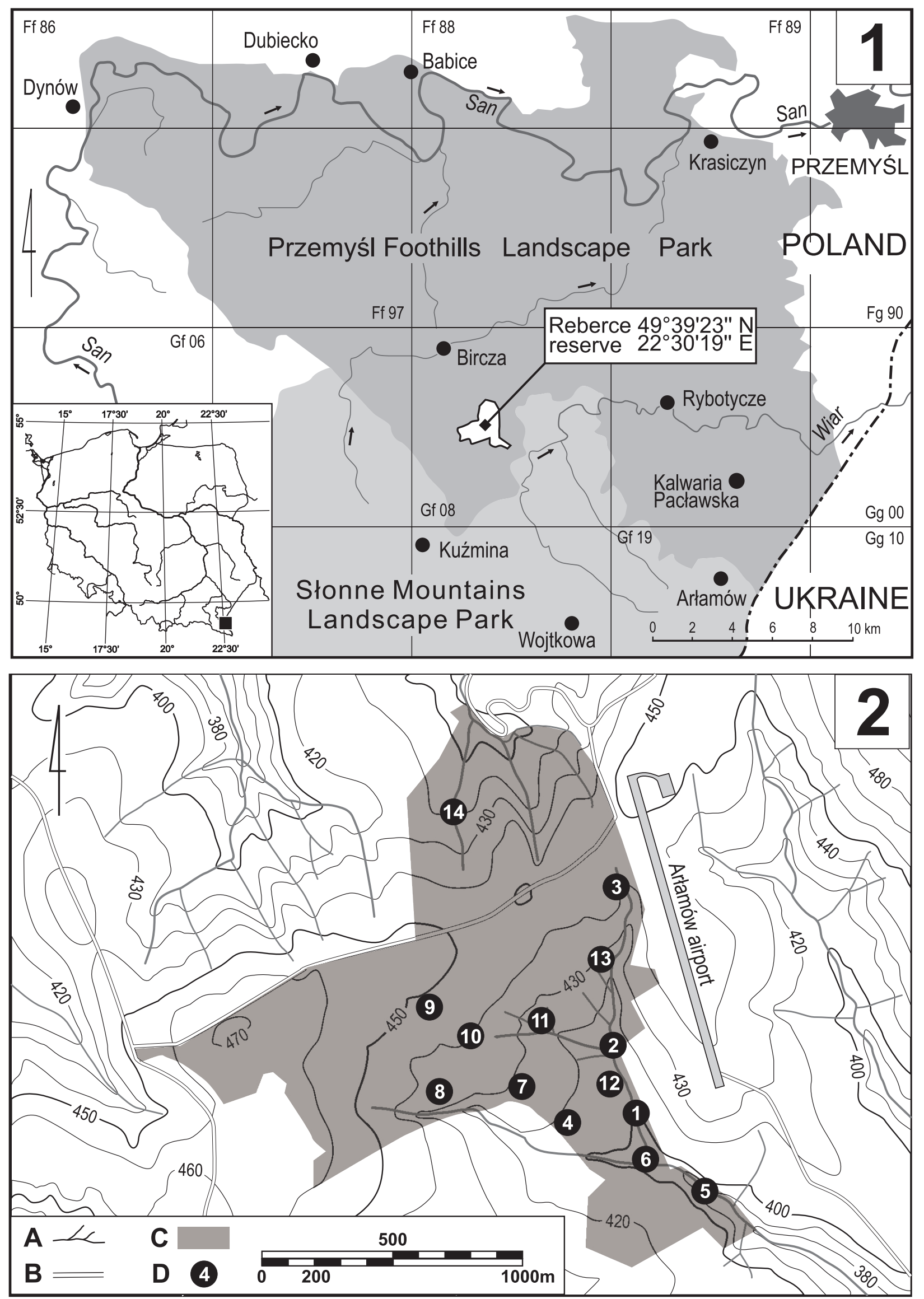

Fig. 1.1 - Localization of the studied area in the Przemyśl Foothills Landscape Park; 2 - Distribution of collecting sites in the Reberce nature reserve; A - rivers, B - roads, C - study area, D - collecting sites 
both in preparation), that fill the gap in knowledge about the poorly described bryoflora of the Przemyśl Foothills and Sanocko-Turczańskie Mountains. Field study was conducted in September 2015 during the $13^{\text {th }}$ Field Workshop organised by the Bryology Section of the Polish Botanical Society.

\section{AREA CHARACTERISTICS}

The Reberce nature reserve lies in the Kiczerka range, a small group of hills in the southern part of the Przemyśl Foothills (the highest point is located at an altitude of $480 \mathrm{~m}$ a.s.1.), overgrown with forests administered by the Bircza Forest District. It includes six forest sections - 143, 144, 152, 153, 154 and 156. Several small streams, which are Wiar and Stupnica tributaries, flow through the reserve. The study area is dominated by floristically rich beech community Dentario glandulosae-Fagetum in its piedmont form. Tree stand, for the most part over 100 years old, is formed mainly by fir Abies alba mixed with beech Fagus sylvatica, elm Ulmus glabra, sycamore Acer pseudoplatanus and spruce Picea abies (JANICKI 2005). The entire reserve is located in Gf 08 ATMOS grid square (OchYRA \& SZMAJDA 1981).

\section{MATERIALS AND METHODS}

The bryophytes were studied at 14 localities (Fig. 1.2) of which most are situated in the central and eastern part of the reserve. Mosses and liverworts were noted on all available types of substrate (soil and humus, rocks, decaying wood and bark of living trees). Based on the number of localities, on which the species was identified, the frequency for each taxon was determined using a four-point scale: rare 1-3 localities, fairly frequent $-4-6$, frequent $-7-9$, common - 10-14. Names for mosses and liverworts follow Ochyra et al. (2003) and Klama (2006b) respectively.

Protected species are qualified according to the Regulation of the Minister of Environment from $9^{\text {th }}$ October 2014 on the protection of plant species (Dz. U. 2014.1409). Endangered species in Poland and Polish part of Carpathians were determined on the basis of the current "Red lists" (ŻARNowIEC et al. 2004, Klama 2006a). Bryophytes which are primeval forest relics were distinguished according to the studies of KLAma $(2002 \mathrm{a}, \mathrm{b})$ and Stebel \& ŻarnowieC (2014). Herbarium materials remain at the disposal of the individual authors.

All samples of bryophyte species were collected in accordance with Polish law and permission of The Regional Directorate for Environmental Protection; clearances no.: WPN.6205.51.2015.AKw-3 (20 July 2015) and WPN.6205.51.2015.AKw-4 (20 July 2015).

\section{RESULTS}

\section{LIST OF SPECIES}

Species on the list are arranged in systematic order. Following information was provided for each species: conservation status (before the names), threat category, frequency, list of localities, types of substrates on which it grew and the author of the collection initials at particular localities.

Abbreviations: ${ }^{* *}$ - strictly protected species; * - partially protected species; threat categories: $\mathrm{E}$ - endangered, $\mathrm{V}$ - vulnerable, $\mathrm{R}$ - rare; loc. - locality; authors: AR - Anna Rusińska, AS - Adam Stebel, BCM - Beata Cykowska-Marzencka, BF - Barbara Fojcik, EF - Ewa Fudali, GV - Grzegorz Vončina, MSK - Monika Staniaszek-Kik, MSZ - Mirosław Szczepański, RZ - Robert Zubel. In the case of the most valuable species GPS coordinates are given.

\section{MARCHANTIOPHYTA}

Conocephalaceae: Conocephalum conicum (L.) Dumort. - fairly frequent (loc.: 1, 2, 6, 7, 13, 14), on wet soil and stone near stream, rarely on rotten wood [AR, BF, EF, GV, MSZ, RZ].

Pelliaceae: Pellia endiviifolia (Dicks.) Dumort. - fairly frequent (loc.: $1,4,5,7,13$ ), wet soil and stone near stream [EF, GV, MSZ, RZ]; Pellia epiphylla (L.) Corda - rare (loc.: 1, 10), soil in valley of the stream [AS, BF, RZ].

Aneuraceae: Riccardia latifrons (Lindb.) Lindb. - fairly frequent (loc.: 1, 6, 7, 9, 14), decaying wood, mainly logs [MSK, MSZ, RZ]; Riccardia multifida (L.) Gray - rare (loc.: 1, 2), soil near stream [RZ]; Riccardia palmata (Hedw.) Carruth. - fairly frequent (loc.: 1, 2, 3, 6, 7), decaying wood, mainly logs [AR, EF, MSK, RZ].

Metzgeriaceae: *Metzgeria conjugata Lindb. - V, frequent (loc.: 1, 2, 3, 7, 8, 10, 13), bark of Abies alba, Carpinus betulus, Fagus sylvatica, Salix caprea and Tilia sp., rarely decaying wood and wet soil near stream [AR, AS, EF, GV, MSK, RZ]; Metzgeria furcata (L.) Dumort. - rare (loc.: 2, 7) on the bark of Carpinus betulus and Salix caprea [MSZ, RZ].

Trichocoleaceae: *Trichocolea tomentella (Ehrh.) Dumort. - frequent (loc.: 1, 2, 6, 7, 8, 9, 11, 12, 14), moist soil near streams, rarely decaying wood [AR, AS, BF, EF, GV, MSK, MSZ, RZ].

Pseudolepicoleaceae: Blepharostoma trichophyllum (L.) Dumort. - fairly frequent (loc.: 1, 2, 5, 7, 10, 13), decaying wood, mainly logs, wet soil, stones and base of trees (Salix caprea, Tilia sp.) [AS, EF, GV, MSK, MSZ, RZ].

Geocalycaceae: Chiloscyphus polyanthos (L.) Corda - rare (loc.: 10), moist soil near stream [AS]; Lophocolea bidentata (L.) Dumort. - fairly frequent (loc.: 1, 2, 6, 8), moist soil near stream, wet soil 
in herb community with Chaerophyllum hirsutum, rarely decaying logs [BF, GV, MSK]; Lophocolea heterophylla (Schrad.) Dumort. - fairly frequent (loc.: 1, 3, 6, 10), decaying wood [AS, EF, GV, MSK, RZ].

Plagiochilaceae: *Plagiochila asplenioides (L. emend. Taylor) Dumort. - frequent (loc.: 1, 2, 6, 7, 8, 11, $12,14)$, bare soil (mainly near stream) and humus, decaying logs, stones in the stream and base of trunks of Tilia sp. [AR, AS, BF, EF, GV, MSK, RZ]; Plagiochila porelloides (Torrey ex Nees) Lindenb. - fairly frequent (loc.: 1, 2, 6, 7, 12, 13), decaying stumps and logs, base of trunks Abies alba, Fagus sylvatica, Salix caprea [AR, AS, BF, EF, GV, MSK, RZ].

Calypogeiaceae: Calypogeia azurea Stotler \& Crotz fairly frequent (loc.: 1, 2, 4, 6, 7), moist soil and stones near stream as well as rotten wood [AR, GV, MSK, RZ]; Calypogeia integristipula Steph. rare (loc.: 8), decaying stump [AR]; Calypogeia muelleriana (Schiffn.) Müll. Frib. - fairly frequent (loc.: 1, 2, 3, 4, 9, 14), rotten wood and mineral soil in the forest and near the stream [EF, MSK, RZ]; Calypogeia suecica (Arnell \& J. Perss.) Müll. Frib. - V; rare (loc.: 1, 6), decaying logs [GV, MSK, RZ].

Lepidoziaceae: *Bazzania trilobata (L.) Gray - fairly frequent (loc.: 1, 9, 10, 14), moist soil and rotten wood [AR, AS, MSK, MSZ, RZ]; Lepidozia reptans (L.) Dumort. - frequent (loc.: 1, 2, 3, 6, 7, 9, 12, $13,14)$, decaying logs and stumps, rarely base of trunks Abies alba and mineral soil [AR, BF, EF, GV, MSK, MSZ, RZ].

Cephaloziaceae: Cephalozia bicuspidata (L.) Dumort. - frequent (loc.: 1, 2, 3, 4, 5, 6, 10), rotten wood and moist soil near the stream, rarely humus and stones in the stream [AS, EF, GV, MSK, RZ]; **Cephalozia catenulata (Huebener) Lindb. - V, fairly frequent (loc.: 1, 2, 5, 6, 9), moist, rotten wood, especially large Abies alba logs [MSK, RZ]; Cephalozia lunulifolia (Dumort.) Dumort. - rare (loc.: 1, 2, 6), rotten wood [MSK, RZ]; *Nowellia curvifolia (Dicks.) Mitt. - V, fairly frequent (loc.: $1,5,9,10,14)$, rotten wood, mainly logs [AS, GV, MSK, MSZ, RZ].

Jungermanniaceae: Jungermannia atrovirens Dumort. - rare (loc.: 1, 7), sandstone stones in the stream [GV, MSK]; Jungermannia leiantha Grolle - fairly frequent $(1,2,5,6,7)$, rotten wood and moist soil by the stream [GV, MSK, RZ]; Jungermannia pumila With. - rare (loc.: 1, 2, 5), soil and stones in the stream bed [RZ].

Lophoziaceae: Jamesoniella autumnalis (DC.) Steph. - fairly frequent (loc.: 1, 2, 3, 13), trunks of Salix caprea, rotten wood, humus and stone in stream bed [EF, GV, RZ].

Scapaniaceae: Scapania undulata (L.) Dumort. - rare (loc.: 13), moist soil [EF].
Jubulaceae: *Frullania dilatata (L.) Dumort. - rare (loc.: 3), decaying log [EF].

Lejeuneaceae: Lejeunea cavifolia (Ehrh.) Lindb. rare (loc.: 14), trunk of Fagus sylvatica (near the stream) [RZ].

Radulaceae: Radula complanata (L.) Dumort. - fairly frequent (loc.: 1, 2, 3, 13), trunks of trees (Abies alba, Salix caprea) and rotten wood [EF, GV, RZ].

\section{BRYOPHYTA}

Sphagnaceae: *Sphagnum capillifolium (Ehrh.) Hedw. - rare (loc.: 3 ), soil [EF]; ${ }^{*}$ Sphagnum girgensohnii Russow - rare (loc.: 9), soil [AR, MSK, MSZ]; *Sphagnum palustre L. - rare (loc.: 3, 10), soil and wet humus [AS, EF, MSK]; *Sphagnum squarrosum Crome - rare (loc.: 8, 9), soil [AR, MSK, MSZ].

Polytrichaceae: Atrichum undulatum (Hedw.) P. Beauv. - common (loc.: 1, 2, 3, 4, 7, 8, 9, 10, 12, 13), exposed soil and humus in the forest and near the stream, root plate of uprooting trees, decaying logs [AR, AS, EF, GV, MSK, RZ]; Polytrichastrum formosum (Hedw.) G.L. Sm. - common (loc.: 1, 2, 3, 4, 6, 7, 8, 9, 10, 12, 13), soil, humus, root plate of uprooting trees and decaying logs [AR, AS, BF, EF, GV, MSK, MSZ, RZ]; *Polytrichum commune Hedw. - rare (loc.: 1), rotten wood near the stream [RZ].

Tetraphidaceae: Tetraphis pellucida Hedw. - frequent (loc.: 1, 2, 3, 6, 7, 10, 13), decaying logs and stumps, base of trees of Abies alba and root plates of uprooting trees $[\mathrm{AR}, \mathrm{AS}, \mathrm{BF}, \mathrm{EF}, \mathrm{GV}, \mathrm{MSK}$, MSZ, RZ].

Buxbaumiaceae: **Buxbaumia viridis (Moug. ex Lam. \& DC.) Brid. ex Moug. \& Nestl. - E, rare (loc.: 6 - N 49³9'01.4", E 22³0'45.2"), moist, decaying logs of Abies alba [AR, BCM, MSK, MSZ].

Fissidentaceae: Fissidens bryoides Hedw. - fairly frequent (loc.: 1, 2, 3, 8), moist soil and boulders in the stream [BF, GV, MSZ, RZ]; Fissidens pusillus (Wilson) Milde - rare (loc.: 5, 7, 11), boulders and moist soil in the stream [AS, MSK, RZ]; Fissidens taxifolius Hedw. - fairly frequent (loc.: 1, 2, 6,12 ), steep slopes soil, moist soil and boulders in the stream bed, root plate of uprooting trees [BF, EF, GV, MSK, MSZ].

Dicranaceae: Dichodontium pellucidum (Hedw.) Schimp. - frequent (loc.: 1, 2, 5, 6, 7, 8, 11, 12) stones, moist soil and gravel in the stream bed [AR, AS, BF, EF, GV, MSK, MSZ, RZ]; Dicranella heteromalla (Hedw.) Schimp. - frequent (loc.: $1,2,3,7,8,9,10,13)$, mineral soil, decaying logs, root plates of uprooting trees, base of trees [AR, AS, BF, EF, MSK, MSZ, RZ]; Dicranella varia (Hedw.) Schimp. - rare (loc.: 7), moist, loamy soil in the stream bed [AR, MSK]; Dicranodontium denudatum (Brid.) E. Britton - common (loc.: 1, 
$2,3,6,7,8,9,10,12,13)$, decaying stumps and logs, humus [AR, AS, BF, EF, GV, MSK, MSZ, RZ]; ${ }^{*}$ Dicranum polysetum Sw. - rare (loc.: 1), mineral soil near the stream [RZ]; ${ }^{*}$ Dicranum scoparium Hedw. - frequent (loc.: 1, 2, 6, 7, 8, 10, 12, 13), decaying logs, bark of trees (Abies alba, Corylus avellana, Salix caprea), soil and humus in forest [AR, AS, BF, EF, GV, MSK, MSZ, RZ]; Orthodicranum montanum (Hedw.) Loeske - frequent (loc.: $1,3,6,7,8,9,10,12,13$ ), bark of trees (Abies alba, Corylus avellana, rotten wood [AR, AS, BF, EF, GV, MSK, MSZ].

Orthotrichaceae: *Orthotrichum lyellii Hook. \& Taylor - R, rare (loc.: 3), bark of Abies alba [EF]; Orthotrichum pumilum Sw. - rare (loc.: 1), bark of Acer pseudoplatanus [GV]; Orthotrichum speciosum Nees - rare (loc.: 13), decaying log [EF]; Orthotrichum stramineum Hornsch. ex Brid. - V, rare (loc.: 1), bark of Acer pseudoplatanus [GV]; *Ulota crispa (Hedw.) Brid. - V, rare (loc.: 1), bark of Corylus avellana [GV].

Bryaceae: Pohlia melanodon (Brid.) A.J. Shaw - rare (loc.: 1, 3), wet soil near the stream [BF]; Pohlia nutans (Hedw.) Lindb. - rare (loc.: 1, 2), mineral soil near the stream [RZ]; Pohlia wahlenbergii (F. Weber \& D. Mohr) A.L. Andrews - rare (loc.: 1, $3,7)$, moist soil and stone near the stream [AR, BF, GV, MSK, MSZ]; Rosulabryum moravicum (Podp.) Ochyra \& Stebel - rare (loc.: 10), bark of tree $[\mathrm{AS}]$.

Cinclidiaceae: Rhizomnium punctatum (Hedw.) T.J. Kop. - frequent (loc.: 1, 2, 3, 6, 7, 8, 10, 12, 13), decaying logs, wet stone and mineral soil [AR, AS, BF, EF, GV, MSK, MSZ, RZ].

Plagiomniaceae: Plagiomnium affine (Blandow ex Funck) T.J. Kop. - frequent (loc.: 1, 2, 3, 6, 7, 8, 9, $10,13)$, soil and humus on the slopes along the stream and decaying logs in the forest [AR, AS, BF, EF, GV, MSK, MSZ, RZ]; Plagiomnium elatum (Bruch \& Schimp.) T.J. Kop. - rare (loc.: 1), moist soil in communities of tall herb near the stream [BF, GV]; Plagiomnium undulatum (Hedw.) T.J. Kop. - frequent (loc.: 1, 2, 3, 6, 7, 8, 13), moist soil and humus along streams and springs [AR, BF, EF, GV, MSK, MSZ, RZ].

Echinodiaceae: Isothecium alopecuroides (Lam. ex Dubois) Isov. - frequent (loc.: 1, 2, 6, 7, 8, 10, 12, 13), trunks and bases of deciduous trees (Carpinus betulus, Populus tremula) and coniferous trees (Abies alba), stones and rotting logs [AR, AS, BF, EF, GV, MSZ].

Pterigynandraceae: Pterigynandrum filiforme Hedw. rare (loc.: 1), rotten wood of Abies alba [GV].

Thuidiaceae: ${ }^{*}$ Thuidium tamariscinum (Hedw.) Schimp. - common (loc.: 1, 2, 3, 4, 6, 7, 8, 9, 10, $12,13)$, mineral soil, humus, rotten wood, tree bases of Abies alba [AR, AS, BF, EF, GV, MSK, MSZ, RZ].
Hylocomiaceae: *Pleurozium schreberi (Willd. ex Brid.) Mitt. - frequent (loc.: 1, 2, 7, 8, 9, 10, 12, 13), mineral soil and humus, decaying logs [AR, $\mathrm{BF}, \mathrm{EF}, \mathrm{GV}, \mathrm{MSK}, \mathrm{RZ}]$; *Rhytidiadelphus squarrosus (Hedw.) Warnst. - rare (loc.: 1), mineral soil [GV]; Rhytidiadelphus subpinnatus (Lindb.) T.J. Kop. - fairly frequent (loc.: 1, 2, 3, 8, 9, 10), moist soil and humus, decaying logs [AR, AS, BF, EF, MSK, MSZ, RZ].

Cratoneuraceae: Cratoneuron filicinum (Hedw.) Spruce - fairly frequent (loc.: 1, 2, 6, 7, 11, 12), moist soil and boulders in the streams [AR, AS, BF, EF, GV, MSK].

Brachytheciaceae: Brachytheciastrum velutinum (Hedw.) Ignatov \& Huttunen - frequent (loc.: 1, $2,3,6,8,10,13)$, decaying logs, bark of deciduous trees Carpinus betulus and Salix caprea, mineral soil and boulders [AR, AS, BF, EF, GV, MSK, RZ]; Brachythecium rivulare Schimp. - fairly frequent (loc.: $3,6,7,8,11$ ), wet logs and boulders in the stream, mineral soil in springs and marshes [AR, AS, EF, MSK]; Brachythecium rutabulum (Hedw.) Schimp. - fairly frequent (loc.: 1, 2, 8, 10, 13), rotten wood, mineral soil and base of trees (Salix sp.) [AR, AS, BF, EF, GV]; Brachythecium salebrosum (Hoffm. ex F. Weber \& D. Mohr) Schimp. - fairly frequent (loc.: 2, 3, 7, 10), rotten wood (logs), tree trunks and boulders [AS, BF, EF, MSK]; Cirriphyllum piliferum (Hedw.) Grout - fairly frequent (loc.: 1, 2, 6, 8), mineral soil in communities of tall herbs near the stream, humus, rotting logs and base of trees (Salix sp.) [AR, BF, GV, MSK]; ${ }^{*}$ Eurhynchium angustirete (Broth.) T.J. Kop. - frequent (loc.: 1, 2, 3, 6, 7, 8, 10, 12, 13), soil, humus, rotting logs and bark of deciduous trees (Fagus sylvatica, Tilia sp.) [AR, AS, BF, EF, GV, MSK, MSZ, RZ]; Kindbergia praelonga (Hedw.) Ochyra - rare (loc.: 6), decaying log [MSK]; Oxyrrhynchium hians (Hedw.) Loeske - fairly frequent (loc.: 1, 2, $4,11,13)$, mineral soil in the forest and on steep slopes near the stream, decaying logs of Abies alba [AS, GV, RZ]; Oxyrrhynchium speciosum (Brid.) Warnst. - rare (loc.: 1, 2, 7), moist soil and rocks in the bed of the stream [BF, MSK]; Torrentaria riparioides (Hedw.) Ochyra (= Platyhypnidium riparioides (Hedw.) Dixon) - fairly frequent (loc.: 1, $7,8,11)$, boulders in the stream [AS, GV, MSZ]; ${ }^{*}$ Pseudoscleropodium purum (Hedw.) M. Fleisch. ex Broth. - rare (loc.: 1, 8), soil and humus in the fir forest [BF, GV, MSK]; Rhynchostegium murale (Hedw.) Schimp. - rare (loc.: 6), stone [MSZ]; Sciuro-hypnum oedipodium (Mitt.) Ignatov \& Huttunen - rare (loc.: 8), soil and humus [MSK]; Sciuro-hypnum populeum (Hedw.) Ignatov \& Huttunen - rare (loc.: 7, 10), base of trees and stone [AS, MSK]; Sciuro-hypnum reflexum (Starke) Ignatov \& Huttunen - rare (loc.: 6), rotten wood [MSZ]. 
Plagiotheciaceae: Plagiothecium cavifolium (Brid.) Z. Iwats. - rare (loc.: 1, 2, 8), soil on the steep and sandy slope [AR, BF]; Plagiothecium curvifolium Schlieph. ex Limpr. - fairly frequent (loc.: 1, 3, 10, 13), exposed soil on a slope, base of trees (Abies alba) and rotting logs [AS, BF, EF]; Plagiothecium denticulatum (Hedw.) Schimp. - rare (loc.: 7), soil on root plate of uprooting tree [MSK]; Plagiothecium laetum Schimp. - fairly frequent (loc.: 1, 2, $3,9,13)$, rotting logs and base of trees (Abies alba) [AR, BF, EF, GV]; Plagiothecium nemorale (Mitt.) A. Jaeger - fairly frequent (loc.: 1, 7, 8, 10, 13), mineral soil and humus on steep slopes and in the bed of the stream, bark of trees (Corylus avellana, Salix caprea) [AR, AS, BF, EF, GV, MSK, MSZ].

Amblystegiaceae: Amblystegium serpens (Hedw.) Schimp. - rare (loc.: 2), bark of Acer pseudoplatanus [BF]; Campylium stellatum var. protensum (Brid.) Bryhn - rare (loc.: 1, 6, 7), soil and moist fir rotten logs [AR, GV, MSZ]; Campylophyllopsis calcarea (Crundwell \& Nyholm) Ochyra - rare (loc.: 1), sandstone in the bed of the stream [GV]; Hygrohypnum luridum (Hedw.) Jenn. - rare (loc.: $1,7,11)$ boulders in the stream [AR, AS, BF, GV, MSK, MSZ]; Sanionia uncinata (Hedw.) Loeske fairly frequent (loc.: 1, 2, 7, 10, 12, 13), rotting logs, boulders in the stream, mineral soil and bark of deciduous trees (Corylus avellana, Populus tremula, Salix caprea) [AS, BF, EF, GV, MSK, MSZ, RZ].

Hypnaceae: Callicladium haldanianum (Grev.) H.A. Crum - rare (loc.: 1, 3, 10), on rotting logs of Abies alba [AS, EF, GV]; *Calliergonella cuspidata (Hedw.) Loeske - rare (loc.: 12), moist soil in the bed of the stream [EF]; ${ }^{*}$ Ctenidium molluscum (Hedw.) Mitt. - rare (loc.: 3, 7), decaying $\log$ and sandstone in the bed of the stream [EF, MSZ]; Herzogiella seligeri (Brid.) Z. Iwats. - frequent (loc.: 1, 2, 3, 6, 7, 8, 9, 10, 12), rotting logs, stones, humus and mineral soil on steep slopes near the stream [AR, AS, BF, EF, GV, MSK, MSZ, RZ]; Hypnum cupressiforme Hedw. var. cupressiforme - frequent (loc.: 1, 2, 3, 6, 7, 8, 10, 12, 13), trunks and bases of deciduous trees (Abies alba, Alnus glutinosa, Carpinus betulus, Corylus avellana, Fagus sylvatica), rotting logs and stumps and mineral soil and humus on steep slopes near the stream [AR, AS, BF, EF, GV, MSK, MSZ]; Hypnum cupressiforme var. filiforme Brid. - rare (loc.: 8), bark of withered Salix caprea [MSK]; Hypnum pallescens (Hedw.) P. Beauv. - rare (loc.: 1, 3, 10), bark of trees and rotting logs [AS, EF, GV]; Platygyrium repens (Brid.) Schimp. - rare (loc.: 10), bark of tree [AS].

\section{GENERAL CHARACTERISTICS OF BRYOPHYTE FLORA}

In the Reberce nature reserve, 33 species of liverworts and 72 taxa of mosses were found. Almost half of the species (49\%) were classified as rare, $29 \%$ as fairly frequent, $18 \%$ as frequent, and only $4 \%$ as common taxa. Atrichum undulatum, Dicranodontium denudatum, Polytrichastrum formosum and Thuidium tamariscinum were the most common species. Trichocolea tomentella, a protected liverwort, known in Poland from scattered localities, was frequently found in the reserve.

\section{HABITAT ANALYSIS}

Among the species found during the research, terrestrial bryophytes were the largest group (66 species $-63 \%)$. They occur abundantly in the undergrowth, growing both on mineral soil and humus. Epigean mosses are also a constant component overgrowing pits, mounds and root plates of uprooted trees. In this type of microhabitats were found, among others: Atrichum undulatum, Dicranella heteromalla, Fissidens taxifolius, Polytrichastrum formosum and Plagiothecium denticulatum. Moist, often steep escarpments of streams flowing through the reserve were characterised by significant species diversity. Brachythecium rivulare, Dicranella heteromalla, Oxyrrhynchium hians, Plagiomnium undulatum, Plagiothecium nemorale and liverworts Calypogeia azurea, Conocephalum conicum, Plagiochila asplenioides, Trichocolea tomentella were highly frequent in this type of habitat. Eroding escarpments along water courses are also an excellent habitat for small mosses of the genus Pohlia ( $P$. melanodon, $P$. wahlenbergii). The Reberce nature reserve is distinguished by the development of diverse epixylic species communities. Specialised epixylic species occur on decaying wood, e.g.: Nowellia curvifolia, Cephalozia catenulata, liverworts of the genus Riccardia (R. palmata and $R$. latifrons), Lepidozia reptans, Tetraphis pellucida and Buxbaumia viridis. In total, 58 species (24 liverworts and 34 mosses), representing $55 \%$ of the whole bryophyte flora, were found on this type of substrate. Epiphytes flora of bryophytes was relatively poorly developed in the reserve. Epiphytic mosses and liverworts were recorded on eight phorophytes, but most taxa was found on firs, willows and hazels. In many cases, only root necks were covered, and only single turfs were observed in the higher parts of the trunks. The following multisubstrate bryophytes grew primarily here: Brachythecium rutabulum, Dicranella heteromalla and Dicranum scoparium; and occasionally typical epiphytes, e.g., Metzgeria furcata, Radula complanata, Orthotrichum stramineum, O. lyellii and Ulota crispa. In total, only 27 taxa were recorded on the bark of trees. On various types of rocks (mostly stones laying in the stream beds), 26 species of mosses and liverworts were found. Campylophyllopsis calcarea, Hygrohypnum luridum, Jungermannia atrovirens, 
Torrentaria (= Platyhypnidium) riparioides and Rhynchostegium murale occurred solely in this habitat.

\section{PROTECTED SPECIES, ENDANGERED SPECIES AND RELICS OF PRIMEVAL FORESTS}

Fairly large number of protected species was found in the bryophyte flora of the Reberce reserve - 17 mosses and seven liverworts. Most of them are partly protected species (mosses - Calliergonella cuspidata, Ctenidium molluscum, Dicranum polysetum, D. scoparium, Eurhynchium angustirete, Orthotrichum lyellii, Pleurozium schreberi, Polytrichum commune, Pseudoscleropodium purum, Rhytidiadelphus squarrosus, Sphagnum capillifolium, S. girgensohnii, S. palustre, S. squarrosum, Thuidium tamariscinum, Ulota crispa; liverworts - Bazzania trilobata, Frullania dilatata, Metzgeria conjugata, Nowellia curvifolia, Plagiochila asplenioides, Trichocolea tomentella), except for two - Buxbaumia viridis and Cephalozia catenulata - which are under strict protection.

Eight species of mosses and liverworts found in the reserve were taxa present in the Red list of endangered species in Poland, including category E (Endangered) - one species: Buxbaumia viridis, V (Vulnerable) - six species: Calypogeia suecica, Cephalozia catenulata, Metzgeria conjugata, Nowellia curvifolia, Orthotrichum stramineum, Ulota crispa, R (Rare) - one species: Orthotrichum lyellii.

Noteworthy are also species considered as indicators of ancient forests (relics of primeval forests). These are: Bazzania trilobata, Buxbaumia viridis, Cephalozia catenulata, Dicranodontium denudatum, Hypnum cupressiforme var. filiforme and Plagiochila asplenioides. They were in almost all localities of the studied reserve.

\section{DISCUSSION}

Not only the type of forest phytocoenoses, but also the availability of suitable habitats and substrates are main factors determining the composition and species richness of bryophytes (ŻARNOWIEC 1995a, KLAмA 2002a, Fојсік 2011). Terrestrial species were the most numerous group in the Reberce nature reserve bryophyte flora. The higher diversity of terrestrial bryophytes resulted from the complex structure of the forest floor, with numerous terrain microforms, such as uprooting trees and steep crumbling escarpments. Fresh soil exposures are particularly important for species with lower competing capacities, including small annual species (ŻARNOWIEC 1995b). A large group of epixylic bryophytes was also found in the reserve. The diversity and richness of this habitat group is caused both by a large amount of decaying wood, and favourable phytoclimatic conditions (high humidity) (CHLEBICKI et al. 1996, KLAMA 2002a). Species of trees of decaying trunks was also the factor determining the development of epixylic species (McAlister 1997, Jansová \& Soldán 2006). Logs of coniferous trees (including firs) were distinguished by the presence of a large group of liverworts and obligatory epixylic species (JansovÁ \& Soldán 2006, TÁBORSKÁ et al. 2015). On the other hand, the presence of fir trees in the stand makes epiphytic flora of rather average quality. Primarily terrestrial and epiphytic communities developed around the root necks. Fir, similarly as other coniferous species, is characterized by considerable poverty of arboreal bryophytes, especially obligatory epiphytes (LISOWSKI 1956, BARKMAN 1958, LÖBEL et al. 2006, MežAKA et al. 2012, FudALI \& WOLSKI 2015).

A high heterogeneity of habitats (the presence of decaying wood, uprooted trees and old tree specimens) is primarily characteristic of stands excluded from continuous forest management. Forests with such a complex structure create the possibility of providing appropriate microhabitats for spore-bearing plants (ŻARNOWIEC 1995a, b, KLAMA 2002a, b). In the Reberce nature reserve, despite relatively poorly diversified vegetation, 105 taxa of mosses and liverworts were found, of which $25 \%$ were endangered and protected species, and therefore the most valuable. The presence of specialised epixylic bryophytes, as well as the presence of a large group of species considered as indicators of primeval forests (CHLEBicki et al. 1996, Klama 2002b, Stebel \& ŻarnowieC 2014), emphasised not only the naturalness of the stands of the reserve, but also the importance of this type of objects for the preservation of bryophyte species diversity.

The list of bryophytes presented in this paper, does not fully reflect the diversity of bryophyte flora. However, it indicates the high natural value of the reserve and fills the gap in the knowledge on bryophyte distribution in Poland.

\section{REFERENCES}

Barabasz-Krasny B., Sottys-Lelek A. (2014): Chronione i zagrożone gatunki mchów oraz roślin naczyniowych na odłogach wielkopowierzchniowych Pogórza Przemyskiego. Roczniki Bieszczadzkie 22: 241-257.

BARKMAN J.J. (1958): Phytosociology and ecology of cryptogamic epiphytes. Van Gorcum, Assen.

Bednarek-Ochyra H., Ochyra R., Stebel A. (2011): The moss genus Niphotrichum (Bryophyta, Grimmiaceae) in the Polish Carpathians. In: A. Stebel, R. Ochyra (eds). Chorological studies on Polish Carpathians Bryophytes. Sorus, Poznań: 15-51.

Chlebicki A., Żarnowiec J., Cieśliński S., Klama H., Bujakiewicz A., Zaeuski T. (1996): Epixylites, lignicolous fungi and their links with different kinds of wood. In: J.B. Faliński, W. Mułenko (eds). Cryptogamous plants in the forest communities of Białowieża National Park. Phytocoenosis 8. (N.S.), Archivum Geobotanicum 6: 75-110. 
Dzwonko Z. (1977): Zbiorowiska leśne Gór Słonnych (Polskie Karpaty Wschodnie). Fragmenta Floristica et Geobotanica 23(2): 161-200.

Fојсік B. (2011): Mchy Wyżyny Krakowsko-Częstochowskiej w obliczu antropogenicznych przemian szaty roślinnej. Wydawnictwo Uniwersytetu Śląskiego, Katowice.

FudALI E., WolsKi G. J. (2015): Ecological diversity of bryophytes on tree trunks in protected forests (a case study from Central Poland). Herzogia 28(1): 91-107.

JANICKI R. (2005): Monografia przyrodniczo-historyczna Parku Krajobrazowego Pogórza Przemyskiego. Zespół Parków Krajobrazowych w Przemyślu, Przemyśl.

JansovÁ I., SoldAn Z. (2006): The habitat factors that affect the composition of bryophyte and lichen communities on fallen logs. Preslia 78: 67-86.

KarczMARz K. (1975): Flora mszaków obszarów lessowych Pogórza Przemyskiego (ekologia, biologia, rozmieszczenie). Rocznik Przemyski 15-16: 319-346.

Klama H. (2002a): Distribution patterns of liverworts (Marchantiopsida) in natural forest communities (Białowieża Primeval Forest, NE Poland). Postdoctoral dissertation. University of Bielsko-Biała, Bielsko-Biała.

Klama H. (2002b): Relikty puszczańskie we florze wątrobowców zbiorowisk leśnych Puszczy Białowieskiej. Zeszyty Naukowe ATH, Inżynieria Włókiennicza i Ochrona Środowiska 7(3): 244260.

Klama H. (2006a): Red list of the liverworts and hornworts in Poland. In: Z. Mirek, K. Zarzycki, W. Wojewoda, Z. Szeląg (eds). Red list of plants and fungi in Poland. Szafer Institute of Botany, Polish Academy of Sciences, Kraków: 21-35.

Klama H. (2006b): Systematic catalogue of Polish liverwort and hornwort taxa. In: J. Szweykowski (ed.). An annotated checklist of Polish liverworts and hornworts. Szafer Institute of Botany, Polish Academy of Sciences, Kraków: 83-100.

KozŁowsKa A. (2000): The forest communities in the Przemyśl Foothills, south-east Poland. Fragmenta Floristica et Geobotanica 45(1-2): 345-372.

LisowsKi S. (1956): Mchy Bieszczadów Zachodnich. Poznańskie Towarzystwo Przyjaciół Nauk, Wydział Matematyczno-Przyrodniczy, Prace Komisji Biologicznej 17(3): 1-85.

LöBel S., SNÄLl T., RYdiN H. (2006): Species richness patterns and metapopulation processes: evidence from epiphyte communities in boreo-nemoral forests. Ecography 29: 169-182.

MCAlister S. (1997): Cryptogam communities on fallen logs in the Duke Forest, North Carolina. Journal of Vegetation Science 8: 115-124.

MežAKA A., Brúmelis G., Piterâns A. (2012): Tree and stand-scale factors affecting richness and compo- sition of epiphytic bryophytes and lichens in deciduous woodland key habitats. Biodiversity and Conservation 21: 3221-3241.

Ochyra R., Szmajda P. (1981): La cartographie bryologique en Pologne. In: J. Szweykowski (ed.). New perspectives in bryotaxonomy and bryogeography. Adam Mickiewicz University, Poznań, Ser. Biologia 20: 105-110.

Ochyra R., Żarnowiec J., Bednarek-Ochyra H. (2003): Census catalogue of Polish mosses. Biodiversity of Poland. Vol. 3. W. Szafer Institute of Botany, Polish Academy of Sciences, Kraków.

Rąkowski G., Walczak M., SMogorzewska M. (2007): Rezerwaty przyrody w Polsce Południowej. Instytut Ochrony Środowiska PAN, Warszawa.

Rehmann A. (1879): Przyczynek do bryologii Galicji. Polska Akademia Umiejętności, Sprawozdanie Komisji Fizjograficznej 13: 139-156.

Stebel A. (2011): Distribution of Orthotrichum lyellii (Bryophyta, Orthotrichaceae) in the Polish Carpathians. In: A. Stebel, R. Ochyra (eds). Chorological studies on Polish Carpathians Bryophytes. Sorus, Poznań: 111-121.

Stebel A., Cykowska B., Żarnowiec J. (2011): Current distribution of the European threatened moss Dicranum viride (Bryophyta, Dicranaceae) in the Polish Carpathians. In: A. Stebel, R. Ochyra (eds). Chorological studies on Polish Carpathians Bryophytes. Sorus, Poznań: 99-111.

Stebel A., Żarnowiec J. (2014): Gatunki puszczańskie we florze mchów Bieszczadzkiego Parku Narodowego (Karpaty Wschodnie). Roczniki Bieszczadzkie 22: 259-277.

SZAFRAN B. (1968): Wykaz mchów zebranych w okolicach Przemyśla. Fragmenta Floristica et Geobotanica 14(2): 237-239.

SzweYKowski J., KoźLIcKA M. (1977): Wątrobowce (Hepaticae). In: J. Szweykowski, T. Wojterski (eds). Atlas rozmieszczenia roślin zarodnikowych w Polsce. Seria 4. Vol. 9. Polska Akademia Nauk, Państwowe Wydawnictwo Naukowe, Warszawa, Poznań: 35.

TÁborská M., P̌̌ívĚtivÝ T., VRšKa T., Ódor P. (2015): Bryophytes associated with two tree species and different stages of decay in a natural fir-beech mixed forest in the Czech Republic. Preslia 87: 387-401.

ZARZECKI R. (2012): Nowe stanowiska Buxbaumia viridis (Buxbaumiaceae, Bryophyta) w południowo-wschodniej Polsce. Fragmenta Floristica et Geobotanica Polonica 19(2): 25-28

Zubel R., Stebel A., Górski P. (2011): Metzgeria conjugata (Marchantiophyta, Metzgeriaceae) in the Polish Carpathians: distribution, ecology and threats. In: A. Stebel, R. Ochyra (eds). Chorological studies on Polish Carpathians Bryophytes. Sorus, Poznań: 133-154. 
ŻARNowiec J. (1995a): Bryopsida. In: J.B. Faliński, W. Mułenko (eds). Cryptogamous plants in the forest communities of Białowieża National Park. Phytocoenosis 7 (N.S.). Archivum Geobotanicum 4: 47-61.

ŻARNOWIEC J. (1995b): Mchy wykrotów w lasach naturalnych niżowej Polski. In: Z. Mirek, J.J. Wójcicki (eds). Szata roślinna Polski w procesie przemian. Materiały konferencji i sympozjów 50. Zjazdu Polskiego Towarzystwa Botanicznego. Kraków 26.0601.07.1995, Kraków: 487.

Żarnowiec J., Stebel A., Ochyra R. (2004): Threatened moss species in the Polish Carpathians in the light of a new Red list of mosses in Poland. In: A. Stebel, R. Ochyra (eds). Bryological studies in the Western Carpathians. Sorus, Poznań: 9-28.

For citation: Staniszek-Kik M., Zubel R., Fudali E., Rusińska A., Fojcik B., Vončina G., Stebel A., SzCZEPAŃSKI M. (2017): A contribution to the moss and liverwort flora of the Reberce nature reserve at the Przemyśl foothills (Western Carpathians, Poland). Steciana 21 (1): 7-15. doi: 10.12657/steciana.021.002 